build up a classified subject, or more correctly an 'ideological' card répertory of simple bibliographical references, which can be filed in duplicate to form an author, title, or generally an 'onomastic' card repertory.

Non-current literature could be gradually dealt with in the same way by systematic reference to accession lists and union catalogues. The records for the non-current literature of a country would take many years to complete, but it is important that the current literature should be attacked as soon as possible before the growing mass gets beyond human control.

By an extension of the exchanging process to the national committees, a great central repertory of all information could be formed, but the enormous mass of references which would accumulate and the space required for storage would make such a proposition impossible to entertain, even if any advantages could be gained by having such a colossal and central national repertory. Each bureau must necessarily be established at an information contre where the material and the card repertories may be stored for use by the information officers and the public.

The application of this proposed organization to British bibliography might be made in either of two ways. The countries of the Empire may be regarded, either in the geographical sense, each with its own national committee and family of bureaux, or the whole British Commonwealth may be grouped under one national committee, which might be called the British Commonwealth Information Committee. With this arrangement the bureaux probably would function as successfully as the twelve branches under the Executive Council of the Imperial Agricultural Bureaux.

Suitable British information centres should be government and public institutions in London, such as the libraries of the Science Museum-for the bureau or bureaux dealing with science and technology - the Victoria and Albert Museum, the Public Record Office and so on. Other libraries and institutions in different parts of the country should be authorized to obtain copies of any desired domains of the official card repertories, so that the records could be dispersed over the country for the benefit of the nation.

The organization is thus fundamentally concerned with the analysis and classification of information in the form of simple bibliographical references. Other services such as abstracts, progress reports, the provision of photo-copy, translation, special bibliographies on demand, loan services, etc., should be regarded as services outside the activities of the official international organization. Many of these services are in vigorous activity and obviously should be improved and developed by the use of the complete records filed in the card repertories of the official organization. It is stated in the roport of the British Commonwealth Science Committee, to which reference was made above, that "The case for collaboration in the production of scientific abstracts of high quality for the common use of the Englishspeaking world is very obvious, and would have the strong support of the Committee". If the major abstracting services would agree to collaborate and adopt a method of passing on 'unwanted' matter to the appropriate service, in a manner similar to that described for material 'unwanted' by the official bureaux, the case might be made. The official card repertories unquestionably would greatly assist the abstracting services and help to avoid duplication, more especially if each abstracting service was identified by classification numbers.

This immense international organization with its bureaux all over the world could not, of course, be established in its entirety in the first instance, but there appears to be no reason why the plan should not he initiated by the establishment of an AngloSoviet-American organization, primarily. concerned with British, Russian and American current literature. The literature of other countries could be divided by agreement among the three members of the United Nations, and the work undertaken for any country in this way could be handed over as soon as its national information committee with the necessary bureaux had been established by the assistance of the International Information Council.

\section{X-RAY ANALYSIS GROUP OF THE INSTITUTE OF PHYSICS}

GOR some time past the need has been felt for closer co-operation between the users of X-ray diffraction methods. In industry, for example, many new. applications are being found for these methods, and their simplicity and directness make them valuable additions to industrial testing procedure. Their use may sometimes be entirely empirical, but a sound understanding of the theoretical basis is necessary in order that the practical worker shall both recognize the limitations of his methods and be able to tackle the more unusual problems that are bound occasionally to be presented to him. It is desirable, therefore, that there should be some means for the technician to become acquainted with the latest results of theory, and for academic circles to learn of the problems that X-ray analysis is being called upon to solve.

The need has been partly met by the X-ray Conferences of the Institute of Physies, which were held in Cambridge in 1942 and 1943. Though their support, both from industry and from the universities, was evidence of their success, the Board of the Institute has realized that such conferences can be of only limited value, and has now authorized the formation of an X-ray Analysis Group.

Despite its connexion with the Institute of Physics, it is not intended that the membership should be confined to physicists. Since the formation of the Group has been sponsored by the Institute, the present committee has a strong bias on the side of physics, but it is hoped that it will become more truly representative of the different branches of science as vacancies in it are filled by election.

The inaugural meeting of the Group was held on Saturday, October 16, in the Physics Department of the University of Manchester, at the invitation of the Manchester and District Branch of the Institute. Dr. F. C. Toy was in the chair. The papers read illustrated very well the objects for which the Group was formed.

The main lecture was given by the chairman of the Group, Sir Lawrence Bragg, on "The Physical Optics of X-Ray Analysis". Sir Lawrence emphasized the essential similarity between the diffraction of light by a grating and of X-rays by a crystal, and showed how the same principles can be applied to both. He spoke rather regretfully of the tardiness 
with which the mathematical theory of diffraction has been applied to $\mathrm{X}$-ray problems and said that, now that the theory has been worked out, it is essential that those who use X-ray diffraction methods should make themselves acquainted with it ; the 'Bragg Law' does not contain the whole of the subject.

Sir Lawrence then described the fundamentals of the theory of X-ray diffraction and the essential part that Fourier series play in it. He described how one is led to the concept of the 'reciprocal lattice' and explained, by reference to line gratings, how the theory can be used for the study of crystals deformed in different ways. Finally, he showed how appreciation of the similarity of the diffraction of $\mathrm{X}$-rays and light can help in devising practical methods for crystal analysis. $\mathrm{He}$ described an apparatus for observing diffraction at small angles, and showed how it can bo used for determining directly the intensities of a zone of reflexions given by the projection of any postulated structure. It can also be used for observing the diffraction pattern given by a single molecule or unit of pattern, and there are thus possibilities of working out structures completely by this means. Great advances may be expected when it becomes possible to work out these methods in greater detail.

After an interval for tea and for the inspection of the exhibition that had been arranged, four short papers on industrial applications were read.

Mr. C. W. Bunn, of Imperial Chemical Industries, Ltd., Northwich, showed some einematograph films of growing crystals. These provide a great deal of evidence of the manner in which crystals are formed, and Mr. Bunn emphasized that there is still no complete explanation of all the phenomena observed.

Dr. A. H. Jay, of the United Steel Companies, Stocksbridge, described some results he has obtained on the correlation of the crystal structure, hardness and magnetic properties of some iron - chromium nickel alloys. The face-centred cubic structure changes partly to body-centred cubic when the alloy is drawn into wire, and the changes of structure and hardness can be followed across the section of the wire.

Dr. I. MacArthur described the rotating anode $\mathrm{X}$-ray tube in use at the Textile Physics Laboratory, University of Leeds. This tube differs from others in the smallness of the power it uses; the great efficiency is due to the fineness of its focus. That this is an important factor was shown by slides in the lecture and by prints in the exhibition; for example, there were fibre photographs taken with an exposure of less than a minute that would have taken hours with ordinary apparatus (see NATURE, July 10, p. 38).

Finally, Mr. L. D. Brownlee, of the MetropolitanVickers Electrical Company, Ltd., Manchester, described the use he has made of X-rays in the study of sintered carbides used for tool-tips. The subject is peculiarly suited to X-ray examination, and the information that has been obtained about the equilibrium diagrams of the components has proved extremely useful in understanding the nature of the reactions involved in the process of manufacture.

A lively discussion of the various papers followed. The interest shown and the attendance of nearly three hundred people at the meeting augur well for the future of the Group and of X-ray analysis in general. Further particulars about the Group can be obtained from Dr. H. Lipson, Crystallographic Laboratory, Frese School Lane, Cambridge.

\section{THE FREEDOMS OF SCIENCE}

$\triangle N$ address on "The Freedoms of Science" was $A$ given by Sir Robert Watson-Watt at an open meeting organized by the North-West Area of the Association of Scientific Workers in the Manchester College of Technology on October 18.

Sir Robert said that the demand for more central planning of science comes from people with a passionate sense of social responsibility. This demand has produced fears and fairly widespread opposition, some of which came from distinguished men of science of undoubted sincerity. There is a gap between these points of view, and he believes that it is both narrow and narrowing. The classical definition of science as organized knowledge is confusing, because it suggests a wholly artificial separation between pure science and technology. In Sir Robert's opinion, civilization began in technology, and pure science arose later when technology had made possible the leisure necessary for its pursuit; but to-day the applied scientist uses the same strict criteria of accuracy and logical evaluation as does the pure scientist.

Considering the position in the universities, Sir Robert maintained that pure science is already subject to planning. In addition there is a strong element of industrial planning ; industrial undertakings make subventions to university departments. By whatever means a university is financed there is some form of budgetary control, and this control should be planned.

Sir Robert said he had discovered no debate about the need for some measure of planning in the application of science in war-time, but planning in hope for peace is nobler and more productive than planning for war through fear. One of the benefits of technology is to remove drudgery, but unless its application is planned, the result will be unemployment. A. large part of scientific effort should be diverted to present needs, but pure science should also receive adequate provision. The facilities which the planners demand for pure science are on a scale which, rather curiously, is vastly greater than the 'freedomists' feel to be necessary. No 'direction' of labour in the scientific world is envisaged. The individual man of science must have the freedom to learn, think, choose, work and speak, but must never claim freedom from self-explanation, external criticism and social re. sponsibility. There is a danger from overplanning, but it is slight. A potential Newton might remain mute and inglorious, submerged in a routine tech. nological process, but that is unlikely to happen.

The kind of planning Sir Robert desired would provide for the free exchange of information. Some very successful planning bodies have been set up during the War, and could be copied in times of peace. The structure should be wholly democratic, and should enable the user to meet the research worker and state his requirements, and the research worker to explain what is and is not practicable. It would be necessary to bring the young bench-worker into the council chamber occasionally for this purpose. The planning of science is obtainable easily, smoothly and productively, and without danger to the freediom of fundamental science.

During the discussion, Prof.M.Polanyi said that, unlike Sir Robert, he believed that pure science should not be confused with technology. The search for organized knowlodge, he said, cannot be planned, and it would be disastrous to attempt it. If pure scientists were 